\title{
A Colorimetric Method for the Estimation of Acetoacetate
}

\author{
BY P. G. WALKER* \\ Department of Biochemistry, University of Sheffield
}

(Received 9 July 1954)

The coupling of aromatic diazo compounds with compounds containing a reactive methylene group to form 'mixed' azo compounds (tautomeric with hydrazones) was recognized as a general reaction following Meyer's (1877) synthesis of phenylazoacetoacetic ester from benzenediazohydroxide and ethyl acetoacetate. Japp \& Klingemann (1888) found that when equimolar amounts of acetoacetic acid and benzenediazohydroxide were coupled in acetate buffer, $\mathrm{CO}_{2}$ was eliminated and methylglyoxal $\omega$-phenylhydrazone was formed (eqn. 1, $\mathrm{R}=\mathrm{C}_{6} \mathrm{H}_{5}$ ). Bamberger (1892) showed that, with excess benzenediazohydroxide in the presence of dilute alkali, a second or even a third diazo molecule coupled with acetoacetic acid, forming respectively $N, N^{\prime}$-diphenyl- $C$-acetylformazan and phenylazo( $N, N^{\prime}$-diphenylformazan) (eqns. 2 and $3, \mathrm{R}=\mathrm{C}_{6} \mathrm{H}_{5}$ ).

$$
\begin{aligned}
& \mathrm{CH}_{3} \cdot \mathrm{CO} \cdot \mathrm{CH}_{2} \cdot \mathrm{COOH}+\mathrm{RN}_{2} \mathrm{OH} \\
& \rightarrow \mathrm{CH}_{3} \text {. CO. CH: } \mathrm{NNHR}+\mathrm{CO}_{2}+\mathrm{H}_{2} \mathrm{O} \text {. } \\
& \mathrm{CH}_{3} \cdot \mathrm{CO} \cdot \mathrm{CH}_{2} \cdot \mathrm{COOH}+2 \mathrm{RN}_{2} \mathrm{OH} \\
& \rightarrow \mathrm{CH}_{3} \cdot \mathrm{COC} / \mathrm{N}=\mathrm{NR}+\mathrm{CO}_{2}+2 \mathrm{H}_{2} \mathrm{O} \text {. } \\
& \rightarrow \mathrm{RN}: \mathrm{NC} \aleph_{\mathrm{N}-\mathrm{NHR}}^{\mathrm{N}=\mathrm{NR}}+\mathrm{CH}_{3} \cdot \mathrm{COOH}+\mathrm{CO}_{2}+2 \mathrm{H}_{2} \mathrm{O} \text {. }
\end{aligned}
$$

A similar series of reactions between acetoacetic acid and $p$-nitrobenzenediazohydroxide has not been described. Rosenthal (1949) introduced a method for the estimation of acetoacetate in blood filtrates in which the products formed by coupling acetoacetate with diazotized $p$-nitroaniline were extracted into an immiscible solvent and estimated colorimetrically. The coupling reaction was carried out at an alkaline $\mathrm{pH}$ (unspecified) and the reaction products were not identified but were shown probably to be multiple.

In the present paper, conditions are defined under which even very small amounts of acetoacetate couple quantitatively with an excess of $p$-nitrobenzenediazohydroxide according to eqn. 2 above $\left(\mathrm{R}=p-\mathrm{NO}_{2} \mathrm{C}_{6} \mathrm{H}_{4}\right)$. This reaction has been made the basis of a sensitive and specific method for the estimation of acetoacetate. The method has been applied to the estimation of acetoacetate formed by the oxidation of $\beta$-hydroxybutyrate by liver preparations and to its estimation in blood.

$$
\text { * J. G. Graves Fellow. }
$$

\section{EXPERIMENTAL AND RESULTS}

\section{Materials}

p-Nitroaniline $(0.05 \%, w / v)$ in $0.05 \mathrm{~N}-\mathrm{HCl}$. The $p$-nitroaniline was dissolved by boiling with water and the required amount of $\mathrm{HCl}$. The solution was made up to the mark after cooling.

Diazo reagent. This was prepared immediately before use by adding $3.0 \mathrm{ml}$. $\mathrm{NaNO}_{2}(0.5 \%, \mathrm{w} / \mathrm{v}$; prepared daily) to $20.0 \mathrm{ml}$. $p$-nitroaniline solution. The colourless solution of the diazonium salt was chilled in an ice bath and $7.0 \mathrm{ml}$. $0.2 \mathrm{M}$ sodium acetate were added. Diazotization at room temperature rapidly gives an almost colourless solution of the comparatively stable diazonium salt of $p$-nitroaniline. Addition of sodium acetate brings the reagent to $\mathrm{pH} 4$ and reduces its stability so that chilling is necessary to minimize spontaneous decomposition.

Acetoacetic acid. This was prepared by the complete hydrolysis of recently distilled ethyl acetoacetate according to the method of Ljunggren (1924). The removal of ethanol by vacuum distillation of the hydrolysate was not necessary since this compound did not interfere with the colour reaction for acetoacetate. After neutralizing the hydrolysate and making up to a convenient volume, the solution of acetoacetate was standardized manometrically according to the method of Edson (1935). The solution was stored at $-18^{\circ}$. Restandardization after 30 days showed that about $5 \%$ of the acetoacetate had been lost through spontaneous decomposition. Dilutions of a freshly standardized solution of acetoacetate were used in preparing the calibration curves described below.

Oxaloacetic acid. The methods of Wohl \& Oesterlin (1901) and Wohl \& Claussner (1907) were used. It was dissolved and neutralized with $\mathrm{NaOH}$ immediately before use.

Mitochondrial preparation from rat liver. Freshly dissected chilled rat liver (5 g.) was ground for $2 \mathrm{~min}$. with $0.25 \mathrm{M}$ sucrose solution (50 ml.) in a stainless-steel homogenizer. In this and all subsequent operations the temperature of the tissue was maintained at $0-5^{\circ}$. The ground liver was centrifuged twice at $500 \mathrm{~g}$ for $5 \mathrm{~min}$., the sedimented nuclei, erythrocytes and intact cells being discarded. Mitochondria in the supernatant were sedimented by centrifuging for $20 \mathrm{~min}$. at $2500 \mathrm{~g}$ and washed twice by resuspending in $50 \mathrm{ml}$. buffered saline $(0.135 \mathrm{M}-\mathrm{KCl}$, $4 \mathrm{~mm}-\mathrm{Na}_{2} \mathrm{HPO}_{4}, 8 \mathrm{~mm}-\mathrm{MgCl}_{2}$ and $0.20 \mathrm{M}$ triethanolamine, $\mathrm{pH} \mathrm{7.3)} \mathrm{and} \mathrm{centrifuging} \mathrm{for} 10 \mathrm{~min}$. at the same speed. The final suspension was made in $50 \mathrm{ml}$. of the same buffered saline. For metabolic experiments $2.5 \mathrm{ml}$. of this suspension, containing approximately $10 \mathrm{mg}$. dry weight of tissue, and $1.0 \mathrm{ml}$. additions were present in each duplicate flask. Incubations were carried out at $20^{\circ}$ in air using a Dubnoff Shaking Incubator (Precision Instruments Ltd., Chicago) or at $30^{\circ}$ in standard Warburg vessels with oxygen in the gas space and alkali in the centre well. 
Blood. Human blood was obtained by venepuncture and rat blood from the tail. The samples were heparinized, chilled in an ice bath and assayed within $2 \mathrm{hr}$. of collection.

Microanalyses. These were carried out by Drs Weiler and Strauss, Oxford.

\section{Method}

To $0.5 \mathrm{ml}$. of a neutral solution of acetoacetate in a glassstoppered $10 \mathrm{ml}$. tube were added $0.5 \mathrm{ml}$. M sodium acetateacetic acid buffer, $\mathrm{pH} 5 \cdot 2$, and $3.0 \mathrm{ml}$. freshly prepared diazo reagent. The final $\mathrm{pH}$ was 4:9-5.0. After standing for $30 \mathrm{~min}$. at room temperature (about $22^{\circ}$ ) for colour development, the reaction was stopped by adding $1.0 \mathrm{ml} .5 \mathrm{~N}-\mathrm{HCl}$ and the product extracted by shaking with $4.0 \mathrm{ml}$. ethyl acetate (A.R.). For the reagent blank, water was used in place of acetoacetate solution.

The density of the ethyl acetate layer was read at $440 \mathrm{~m} \mu$. in a $1 \mathrm{~cm}$. cell (Unicam SP. 600 spectrophotometer). This wavelength was selected on the basis of preliminary experiments and was used throughout the present work. From the absorption spectrum of the reaction product (Fig. 2) it can be seen that a wavelength of $450 \mathrm{~m} \mu$. is preferable and this is recommended for future work. The extracted colour was stable for at least $24 \mathrm{hr}$. Acidification with $\mathrm{HCl}$ stopped the coupling reaction, prevented further decomposition of the diazo reagent by restabilizing it as diazonium salt, and reduced the blank colour contributed by decomposition products such as $p$-nitrophenol. Extraction of the reaction product into ethyl acetate was complete, giving density readings inversely proportional to the volume of solvent used.

The almost-linear calibration curve obtained with solutions of acetoacetic acid containing $1-20 \mu \mathrm{g} . / \mathrm{ml}$. is shown in Fig. 1. The range of this calibration curve was extended to cover the direct assay of solutions of acetoacetic acid containing up to $100 \mu \mathrm{g} . / \mathrm{ml}$. by dilution of the final ethyl acetate extract to a convenient optical density. With larger amounts of acetoacetate, colour development became incomplete and preliminary dilution of the solutions was required.

An identical curve was obtained in similar experiments using solutions of acetoacetate in trichloroacetic acid, provided that the solutions were buffered so that the final

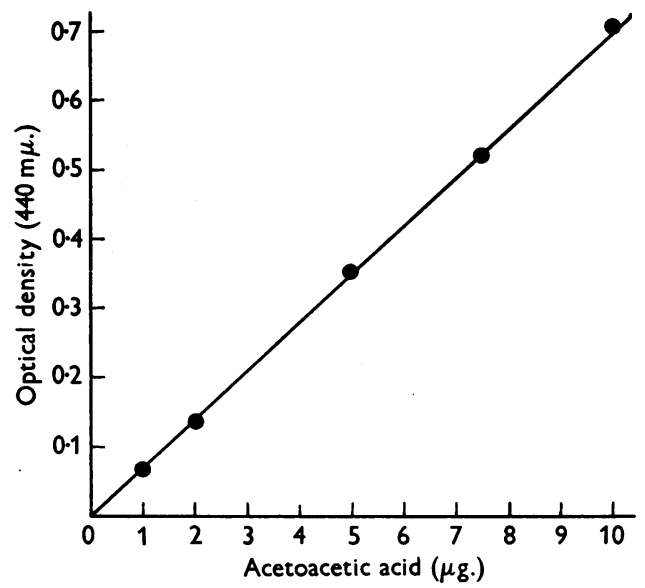

Fig. 1. Calibration curve for the estimation of acetoacetic acid.

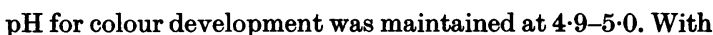
solutions containing, for example, $3 \%(w / v)$ trichloroacetic acid, $0.5 \mathrm{ml}$. $\mathrm{M}$ sodium acetate added in place of acetate buffer gave the required $\mathrm{pH}$.

\section{Isolation and identification of the product of the coupling reaction}

The product formed on coupling acetoacetate with diazotized $p$-nitroaniline under the conditions described above was insoluble. With small amounts of acetoacetate the reaction mixture became cloudy, with larger amounts a flocculent precipitate formed. In a large-scale experiment this precipitate was isolated, purified and shown to be N, N'-bis-(p-nitrophenyl)-C-acetylformazan. The coupling reaction therefore follows the course described by eqn. $2\left(\mathrm{R}=p-\mathrm{NO}_{2} \mathrm{C}_{6} \mathrm{H}_{4}\right)$.

To $300 \mathrm{ml}$. of a neutral solution of acetoacetate $(0 \cdot 2 \mathrm{mg}$. ml.) were added $300 \mathrm{ml}$. $\mathrm{m}$ sodium acetate, $\mathrm{pH} 5 \cdot 2$, and $1800 \mathrm{ml}$. diazo reagent (molar ratio of $p$-nitroaniline to acetoacetate $=7: 1$ ). After stirring for $20 \mathrm{~min}$. at room temperature the flocculent precipitate which formed was filtered off and dried in vacuo (wt. $203 \mathrm{mg}$., $97 \%$ of theoretical yield). It was recrystallized twice from ethanol in the form of small dark red-brown plates and dried at $50^{\circ}$ in vacuo. The compound was insoluble in water, moderately soluble in acetone and very soluble in ethyl acetate and

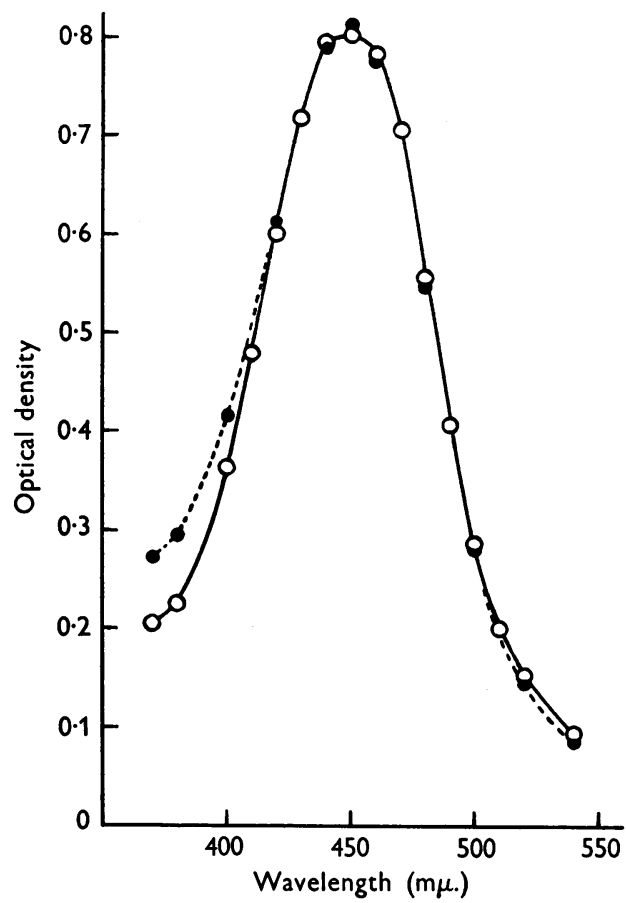

Fig. 2. Absorption spectra of $N, N^{\prime}$-bis-(p-nitrophenyl)- $C$ acetylformazan and of the reaction product formed by coupling acetoacetate with diazotized $p$-nitroaniline. O-O, $N, N^{\prime}$ - bis - ( $p$-nitrophenyl) - $C$ - acetylformazan, $1.00 \mathrm{mg}$. in $100 \mathrm{ml}$. ethyl acetate; - . - , product from $11.5 \mu \mathrm{g}$. acetoacetate coupled under standard conditions (see text) and extracted into $4 \mathrm{ml}$. ethyl acetate. 
benzene. It gave a violet colour with dilute $\mathrm{NaOH}$ and redpurple with concentrated $\mathrm{H}_{2} \mathrm{SO}_{4}$. It had m.p. 217-219 (uncorr.) with decomposition (rate of heating $=10^{\circ} / \mathrm{min}$.) and $\epsilon 440 \mathrm{~m} \mu .=2.85 \times 10^{4}$ in ethyl acetate at $22^{\circ}$ (average of four experiments, range 2.83-2.86 $\times 10^{4}$ ). (Found: $\mathrm{C}$, $50 \cdot 1 ; \mathrm{H}, 3.50 ; \mathrm{N}, 23 \cdot 8 . \mathrm{C}_{15} \mathrm{H}_{12} \mathrm{O}_{5} \mathrm{~N}_{6}$ requires $\mathrm{C}, 50.5 ; \mathrm{H}, 3.37$; $\mathrm{N}, \quad 23.6 \%$.) $\quad N, N^{\prime}$-bis-( $p$-nitrophenyl)- $C$-acetylformazan has not been hitherto described but it is very similar in its properties and colour reactions to $N$-phenyl- $N^{\prime}-p$-nitrophenyl- $C$-acetylformazan (Bamberger \& Lorenzen, 1892).

Fig. 2 shows the absorption spectra of the purified formazan and of the reaction product obtained by coupling acetoacetate and diazotized $p$-nitroaniline under the conditions employed in the assay. Equivalent amounts of formazan and acetoacetate (calculated from eqn. 2) were used and the agreement between the two curves (1-2\% at $450 \mathrm{~m} \mu$.) shows that the reaction described by eqn. 2 takes place quantitatively.

Further evidence in favour of the course described by eqn. 2 was obtained from experiments in which $\mathrm{CO}_{2}$ evolved in the course of the coupling reaction was measured manometrically (Table 1). The molar ratio of $\mathrm{CO}_{2}$ evolved to acetoacetate found by colorimetric assay was close to 1 , except in the case of the largest amount of acetoacetate tested $\left(200 \mu \mathrm{g}\right.$.), where $\mathrm{CO}_{2}$ formation was close to the theoretical but colour development was incomplete.

Under altered reaction conditions the coupling reaction followed the course described by eqn. $\mathrm{l}\left(\mathrm{R}=p-\mathrm{NO}_{2} \mathrm{C}_{6} \mathrm{H}_{4}\right)$ forming methyl glyoxal $\omega$-( $p$-nitrophenylhydrazone). The molar ratio of $p$-nitroaniline to acetoacetate was made $1: 3$ and the final $\mathrm{pH} 4 \cdot 2$. The precipitate was filtered off and recrystallized from ethanol in the form of fine yellow needles, m.p. $209^{\circ}$ (uncorr.) with decomposition commencing at $200^{\circ}$ (rate of heating $10^{\circ} / \mathrm{min}$.). (Found: C, 52.0; H, 4.15; $\mathrm{N}, 20 \cdot 4$. Calc. for $\mathrm{C}_{9} \mathrm{H}_{9} \mathrm{O}_{3} \mathrm{~N}_{3}: \mathrm{C}, 52 \cdot 2 ; \mathrm{H}, 4 \cdot 35 ; \mathrm{N}, 20 \cdot 3 \%$.) This compound gave a dark red colour with dilute $\mathrm{NaOH}$ and a yellow solution in concentrated $\mathrm{H}_{2} \mathrm{SO}_{4}$. Chattaway \& Ashworth (1933) record m.p. $217^{\circ}$ for this compound. Conditions for coupling according to eqn. $3\left(\mathrm{R}=p \cdot \mathrm{NO}_{2} \mathrm{C}_{6} \mathrm{H}_{4}\right)$ were not investigated.

\section{Varying reaction conditions}

The conditions for the coupling reaction were selected on the basis of the following experiments in which the various factors concerned were studied independently.
Fig. 3 shows the time course of colour development with different amounts of acetoacetate under the standard conditions defined above. The curves show that the increase in optical density obtained with acetoacetate rose to a

\section{Table 1. Formation of carbon dioxide on coupling acetoacetate with diazotized $\mathrm{p}$-nitroaniline}

Diazo reagent $(3.0 \mathrm{ml}$.) in the main compartment of the Warburg vessels and $1.0 \mathrm{ml}$. of a standard solution of acetoacetate in $0.5 \mathrm{M}$ acetate buffer, $\mathrm{pH} 5.0$, in the side arm were mixed after equilibration $\left(20 \mathrm{~min}\right.$.; $\left.20^{\circ}\right)$. Gas evolution was measured over a $30 \mathrm{~min}$. period at the end of which $1.0 \mathrm{ml} .5 \mathrm{~N}-\mathrm{HCl}$ was added to the cups. The reaction product was extracted into ethyl acetate for colorimetric estimation. Corrections for the formation of nitrogen and colour by decomposition of the diazo reagent were obtained from control vessels containing no acetoacetate. Results are expressed in $\mu$ moles.

$\begin{array}{ccc}\begin{array}{c}\text { Acetoacetic } \\ \text { acid added }\end{array} & \begin{array}{c}\mathrm{CO}_{2} \\ \text { evolved }\end{array} & \begin{array}{c}\text { Acetoacetic } \\ \text { acid found }\end{array} \\ 0.98 & 1.05 & 1.00 \\ 1.46 & 1.50 & 1.42 \\ 1.96 & 2.01 & 1.81\end{array}$

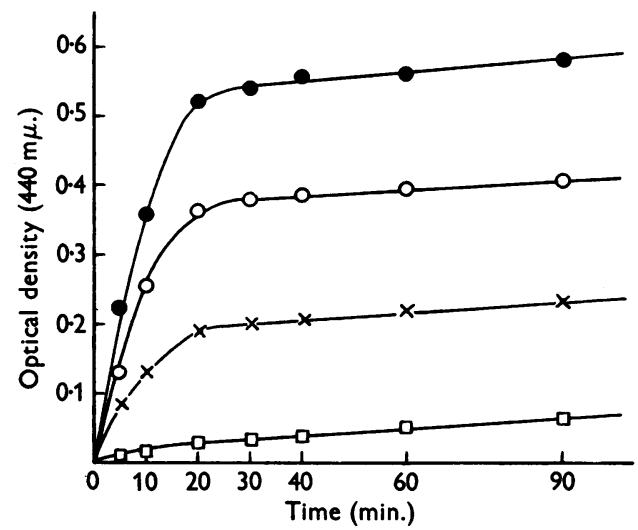

Fig. 3. Time curves for colour development with varying amounts of acetoacetic acid: $-7 \cdot 5 \mu \mathrm{g} \cdot \mathrm{O}-\mathrm{O}$, $5 \cdot 0 \mu \mathrm{g} . ; \times-\times, 2 \cdot 5 \mu \mathrm{g} . ; \square-\square$, reagent blank.

\section{Table 2. Effect of varying conditions on the coupling of acetoacetic acid and p-nitrobenzenediazohydroxide}

The effect of each variable was studied with the others fixed at the values obtaining under standard conditions, viz. concentration of $p$-nitroaniline, $0.05 \%(w / v)$; final $\mathrm{pH}, 5 \cdot 0$; temperature of colour development, $22^{\circ}$. The minimum time for full colour development is shown together with the readings given by acetoacetic acid (5 $\mu$ g.) and the reagent blank at this point.

\begin{tabular}{|c|c|c|c|}
\hline \multirow[b]{2}{*}{ Reaction conditions } & \multirow[b]{2}{*}{$\begin{array}{l}\text { Time } \\
\text { (min.) }\end{array}$} & \\
\hline & & $\begin{array}{l}\text { Acetoacetate } \\
(5 \mu \mathrm{g} .)\end{array}$ & $\begin{array}{c}\text { Reagent } \\
\text { blank }\end{array}$ \\
\hline Standard & 30 & $0 \cdot 380$ & 0.033 \\
\hline \multicolumn{4}{|c|}{ Concentration of $p$-nitroaniline $(\%, \mathrm{w} / \mathrm{v})$ : } \\
\hline $\begin{array}{l}0.025 \\
0 \cdot 100\end{array}$ & $\begin{array}{l}40 \\
20\end{array}$ & $\begin{array}{l}0 \cdot 375 \\
0 \cdot 392\end{array}$ & $\begin{array}{l}0.021 \\
0.053\end{array}$ \\
\hline \multicolumn{4}{|l|}{ Final pH: } \\
\hline $\begin{array}{l}6 \cdot 30 \\
4 \cdot 42\end{array}$ & $\begin{array}{l}20 \\
90\end{array}$ & $\begin{array}{l}0.418 \\
0.368\end{array}$ & $\begin{array}{l}0 \cdot 064 \\
0 \cdot 020\end{array}$ \\
\hline Temperature, $37^{\circ}$ & 15 & $0 \cdot 444$ & 0.082 \\
\hline
\end{tabular}


stable maximum, attained after about $30 \mathrm{~min}$. Proportionality between the increase in density and amount of acetoacetate present was best when the former was maximal.

Time curves similar to those in Fig. 3 were obtained from other experiments in which the concentration of $p$-nitroaniline used for preparing the diazo reagent and the final $\mathrm{pH}$ and temperature at which coupling was carried out were varied. Table 2 shows that the maximum amount of colour obtained from a given amount of acetoacetate, after correction for the reagent blank, was approximately the same over the ranges tested. The rate of colour development, both in the presence of acetoacetate and in the blank, was increased by increasing concentration of diazo reagent, alkalinity and temperature. In other experiments it was shown that the colour obtained was unaltered either by varying the concentration of acetate in the final reaction mixture (pH 5.0) from 0.1 to $0.3 \mathrm{M}$ or by using citrate instead of acetate buffer of the same molarity.

The standard conditions for acetoacetate estimation were selected to give the maximum acetoacetate colour, a low reagent blank and a coupling reaction of reasonably short duration. It should be noted that the colorimetric estimation of acetoacetate by the coupling reaction depends on the reproducibility of the reaction and not on the above demonstration that the conversion to formazan is quantitative. The method was, in fact, calibrated in terms of a manometrically standardized solution of acetoacetate.

\section{Specificity of the reaction}

Under standard conditions the following compounds in amounts of $100 \mu \mathrm{g}$. neither gave any significant amount of colour with the diazo reagent nor did they interfere with the reaction for acetoacetate: acetone, ethanol, glucose, soluble barbitone, 2:4-dinitrophenol, $( \pm)$ - $\beta$-hydroxybutyric acid, $\alpha$-oxoglutaric acid, pyruvic acid and dehydroascorbic acid.

In Table 3 are listed compounds of which $100 \mu \mathrm{g}$. gave density readings exceeding that of the reagent blank by more than 0.010. Of these compounds, only ascorbic acid interfered with the colour given by acetoacetate simultaneously present. This interference was probably due to reduction of $N, N^{\prime}$-bis-( $p$-nitrophenyl)- $C$-acetylformazan, which was found to be slowly decolorized on shaking with a solution of ascorbic acid in acetate buffer, pH 5.0. Interference by ascorbic acid in the estimation of acetoacetate was overcome by preliminary oxidation of the ascorbic acid.

\section{Table 3. Specificity of the reaction for acetoacetic acid}

Substances in the amounts shown were compared under the standard conditions for the assay of acetoacetic acid defined in the text. The values of the optical density have been corrected for the reagent blank.

$\begin{array}{lcc}\text { Substance } & \begin{array}{c}\text { Amount } \\ (\mu g .)\end{array} & \begin{array}{c}\text { Optical } \\ \text { density }\end{array} \\ \text { Acetoacetic acid } & 5 & 0 \cdot 350 \\ \text { Oxaloacetic acid } & 25 & 0 \cdot 565^{*} \\ \text { Malonic acid } & 50 & 0 \cdot 460 \\ \text { L-Ascorbic acid } & 50 & 0 \cdot 214 \\ \text { Sulphanilamide } & 100 & 0 \cdot 065 \\ \text { Ethylacetoacetate } & 100 & 0 \cdot 052 \\ \text { L-Tyrosine } & 100 & 0 \cdot 049 \\ \text { Glycine } & 100 & 0 \cdot 013 \\ \text { Salicylic acid } & 100 & 0.011\end{array}$

* Reaction product unstable.
To $0.5 \mathrm{ml}$. of acetoacetate-ascorbate solution was added $0.5 \mathrm{ml}$. of a solution of $0.001 \mathrm{M}$ cupric acetate in $\mathrm{M}$ acetate buffer (final pH, 5•2), followed by aeration for $15 \mathrm{~min}$. The diazo reagent was then added and the estimation of acetoacetate carried out as usual. This treatment completely abolished interference by ascorbic acid (amounts up to $50 \mu \mathrm{g}$. were tested) without affecting acetoacetate.

The amount of colour given by oxaloacetate was variable since the product of its reaction with the diazo reagent was unstable under these conditions. The colour was maximal after about $20 \mathrm{~min}$. and fading was accelerated by addition of $\mathrm{HCl}$ at $30 \mathrm{~min}$. The residual colour was stable after extraction into ethyl acetate. The estimation of acetoacetate in the presence of oxaloacetate was accomplished by taking advantage of the specific decarboxylation of oxaloacetate by polyvalent cations (Krebs, 1942) and of the instability of the reaction product formed on diazotization. The following technique was adopted: $0.5 \mathrm{ml}$. of the acetoacetato-oxaloacetate solution was shaken for $20 \mathrm{~min}$. at $35^{\circ}$ with $0.5 \mathrm{ml}$. $0.01 \mathrm{M}$ cobaltous acetate in $\mathrm{M}$ acetate buffer (final pH 5.2). Acetoacetate was then estimated in the usual way except that the tubes were allowed to stand for $1 \mathrm{hr}$. at room temperature between the stages of acidification with $\mathrm{HCl}$ and extraction with ethyl acetate. The small amount of colour due to traces of oxaloacetate which escaped decarboxylation was destroyed without reducing the colour due to acetoacetate. $\beta$-Keto acids, other than acetoacetic and oxaloacetic, were not tested but would be expected to react forming other $C$-substituted formazans.

A method of correcting for the small amount of colour given by unknown amounts of phenolic and amino compounds when present along with acetoacetate is described in the next section.

\section{Estimation of acetoacetate in tissue preparations}

When this method was applied to the estimation of acetoacetate in trichloroacetic extracts of tissues it was found that more colour was obtained in assays done on such extracts than from the corresponding reagent blank containing trichloroacetic acid alone. Part of this increase in colour was due not to acetoacetate but to other material (probably phenolic and amino compounds) in the extract, since readings slightly higher than the reagent blank were still obtained using extracts which had been heated on the boiling-water bath for $5 \mathrm{~min}$. This treatment destroyed acetoacetate completely, whereas the material responsible for the residual increase in colour remained unchanged even after heating for $15 \mathrm{~min}$. Acetoacetate levels in tissue extracts were therefore estimated by difference from the readings obtained using fresh and heated extracts.

Liver preparations. At the end of the incubation period, the liver preparations described above were chilled and protein was precipitated by the addition of $0.5 \mathrm{ml}$. trichloroacetic acid $(25 \%, w / v)$. After centrifuging at $0-5^{\circ}$, acetoacetate in the supernatant $(3 \%, w / v$, with respect to trichloroacetic acid) was estimated by adding $0.5 \mathrm{ml}$. of $\mathrm{m}$ sodium acetate and $3.0 \mathrm{ml}$. of diazo reagent to $0.5 \mathrm{ml}$. of the supernatant. For the blank, supernatant was heated for 5 min. on a boiling-water bath and cooled before making these additions. The subsequent procedure was that already described. Supernatants containing more than $100 \mu \mathrm{g}$. acetoacetate $/ \mathrm{ml}$. were diluted with $3 \%(w / v)$ trichloroacetic acid before use. 
Table 4 shows that no acetoacetate was detectable in a suspension of washed mitochondria from rat liver nor was any formed by such a preparation on incubation in the presence of cofactors but without added substrate. It was found in these experiments that the blank colour given by liver preparations remained unchanged on incubation at $20^{\circ}$. A change in the amount of acetoacetate in such a preparation was therefore measured by difference from the initial reading given by the unincubated preparation. The method was capable of detecting acetoacetate in amounts as low as $0.02 \mu \mathrm{mole} /$ flask. The recovery of varying amounts of acetoacetate added to the preparation was good and in agreement with the findings of Lehninger (1949), added acetoacetate was metabolically inert. The low recovery $(92 \%)$ of acetoacetate after $60 \mathrm{~min}$. incubation was duplicated in a control flask containing tissue suspension inactivated by warming for $60 \mathrm{~min}$. at $60^{\circ}$ and was probably

\section{Table 4. Estimation of acetoacetate in washed suspensions of rat liver}

Each flask contained $10 \mu$ moles adenosine triphosphate, $1.5 \mu$ moles diphosphopyridine nucleotide, $0.05 \mu$ mole cytochrome $c$ and $2.5 \mathrm{ml}$. liver suspension. Water, acetoacetate or ( \pm )- $\beta$-hydroxybutyrate were added as indicated making the total volume $3.5 \mathrm{ml}$. Temperature of incubation $20^{\circ}$.

\begin{tabular}{|c|c|c|}
\hline $\begin{array}{l}\text { Substrate } \\
(\mu \text { moles })\end{array}$ & $\begin{array}{c}\text { Period of } \\
\text { incubation } \\
\text { (min.) }\end{array}$ & $\begin{array}{c}\text { Acetoacetate } \\
(\mu \text { moles })\end{array}$ \\
\hline None & $\begin{array}{r}\mathbf{0} \\
\mathbf{3 0}\end{array}$ & $\begin{array}{l}0.02 \\
0.02\end{array}$ \\
\hline Acetoacetate $\left\{\begin{array}{l}0.55 \\
2 \cdot 18 \\
4 \cdot 36 \\
1 \cdot 09\end{array}\right.$ & $\begin{array}{r}0 \\
0 \\
0 \\
0 \\
\mathbf{3 0} \\
60\end{array}$ & $\begin{array}{l}0 \cdot 53 \\
2 \cdot 23 \\
4 \cdot 25 \\
1 \cdot 09 \\
1 \cdot 07 \\
1 \cdot 02\end{array}$ \\
\hline$\beta$-Hydroxybutyrate $(80 \mu$ moles $)$ & $\begin{array}{l}0 \\
2 \cdot 5 \\
5 \\
10 \\
20 \\
30 \\
60\end{array}$ & $\begin{array}{l}0 \\
0 \cdot 71 \\
1 \cdot 35 \\
2 \cdot 21 \\
3 \cdot 80 \\
4 \cdot 92 \\
7 \cdot 16\end{array}$ \\
\hline
\end{tabular}

Table 5. Oxygen uptake and acetoacetate formation due to oxidation of $\beta$-hydroxybutyrate by washed suspension of rat liver

After temperature equilibration, $160 \mu$ moles ( \pm )- $\beta$ hydroxybutyrate, $35 \mu$ moles $\mathrm{NaF}, 10 \mu$ moles adenosine triphosphate, $1.5 \mu$ moles diphosphopyridine nucleotide and $0.05 \mu$ mole cytochrome $c$ were added from the side arm to $2.5 \mathrm{ml}$. liver suspension in the main compartment of the Warburg flasks. Total volume $3.5 \mathrm{ml}$. Temp. $30^{\circ}$.

\begin{tabular}{|c|c|c|c|}
\hline \multirow[b]{2}{*}{$\begin{array}{l}\text { Period of } \\
\text { incubation } \\
\text { (min.) }\end{array}$} & \multirow{2}{*}{$\begin{array}{c}\text { Oxygen } \\
\text { uptake } \\
\text { ( } \mu \mathrm{g} . \text { atoms) }\end{array}$} & \multicolumn{2}{|c|}{$\begin{array}{c}\text { Acetoacetate } \\
(\mu \text { moles })\end{array}$} \\
\hline & & $\begin{array}{l}\text { Manometric } \\
\text { estimation }\end{array}$ & $\begin{array}{l}\text { Colorimetric } \\
\text { estimation }\end{array}$ \\
\hline $\begin{array}{l}15 \\
30 \\
60\end{array}$ & $\begin{array}{r}6 \cdot 95 \\
12 \cdot 08 \\
19 \cdot 25\end{array}$ & $\begin{array}{r}6.90 \\
11 \cdot 71 \\
18 \cdot 44\end{array}$ & $\begin{array}{r}6 \cdot 81 \\
11 \cdot 70 \\
18 \cdot 10\end{array}$ \\
\hline
\end{tabular}

Table 6. Levels of acetoacetic acid in blood

Results expressed as mean concentration found in the number of subjects shown by the figures in parentheses.

$\begin{array}{lc}\text { Subjects } & \begin{array}{c}\text { Acetoacetic acid } \\ (\mathrm{mg} / 100 \mathrm{ml} . \text { blood })\end{array} \\ \begin{array}{l}\text { Human } \\ \text { Normal (untreated) }\end{array} & 0 \cdot 31(5) \\ \text { acid/100 ml. blood added) } & 10 \cdot 27(5) \\ \text { Diabetes with ketonuria (3 cases) } & \left\{\begin{array}{l}12 \cdot 81 \\ 11 \cdot 55 \\ 18 \cdot 62\end{array}\right. \\ \text { Rat } & 0 \cdot 42(6) \\ \text { Normal } & 3 \cdot 14(4) \\ \text { Fasted } 24 \mathrm{hr} . & \end{array}$

due to spontaneous decomposition (cf. Krebs \& Eggleston, 1945). Table 4 also shows that acetoacetate was formed by the oxidation of $\beta$-hydroxybutyrate at a rate which was initially constant but which gradually declined on prolonging the incubation.

The experiment described in Table 5 demonstrated the equivalence of acetoacetate assays done by the present method and the manometric method of Edson (1935). This experiment also showed that the ratio $\mu$ g. atoms $\mathrm{O}_{2}$ utilized to $\mu$ moles acetoacetate formed was close to 1 (cf. Lehninger \& Smith, 1949). In the absence of $\beta$-hydroxybutyrate, no acetoacetate was formed and the oxygen uptake was about $7 \%$ of the uptake observed in the presence of substrate.

Blood. Protein was precipitated by adding $1 \mathrm{ml}$. blood to $4 \mathrm{ml}$. cold $6 \cdot 25 \%(\mathrm{w} / \mathrm{v})$ trichloroacetic acid. After centrifuging, the supernatant was decanted and filtered to clear if necessary. The procedure for estimation of acetoacetate in the supernatant $(5 \%, w / v$, with respect to trichloroacetic acid) was the same as that used for extracts of liver except that $1.4 \mathrm{M}$ instead of $\mathrm{M}$ sodium acetate was used to bring the final $\mathrm{pH}$ to $5 \cdot 0$ for the coupling reaction. Emulsions which sometimes formed during the final extraction with ethyl acetate were broken by a short centrifuging.

Table 6 shows the levels of acetoacetate found in normal human and rat whole blood. The figures agree with normal values obtained by other methods (Stark \& Somogyi, 1943; Rosenthal, 1949; El Hawary \& Thompson, 1953). There was good recovery of acetoacetate added to the samples of human blood. The high levels found in diabetics with ketonuria fell in each case to $<0.5 \mathrm{mg} . / 100 \mathrm{ml}$. within 5 days of commencing treatment. The rapid onset of ketonaemia in fasting rats (MacKay, Carne, Wick \& Visscher, 1941; Rosenthal, 1949) was confirmed.

It should be noted that the amount of acetoacetate in a trichloroacetic acid extract of normal blood is near the lower limit which can be estimated. As here described, the method is better suited to the estimation of significantly raised values than to the detection of variations within the normal range.

\section{DISCUSSION}

Although similar in principle, the method described here has the following advantages over that of Rosenthal (1949):

(1) The conditions employed result in the reproducible and quantitative conversion of acetoacetate into a single known compound which is 
completely extracted from the reaction mixture and directly assayed.

(2) The method can be applied to the estimation of acetoacetate in tissue extracts as well as in blood filtrates.

(3) There is no interference by pyruvic acid.

Other methods available for estimating small amounts of acetoacetate are based on its quantitative decomposition to acetone and $\mathrm{CO}_{2}$. The present method compares well in its simplicity, specificity and sensitivity with the micromethods of Greenberg \& Lester (1944) and of Stadtman, Doudoroff \& Lipmann (1951).

\section{SUMMARY}

1. A colorimetric method for the estimation of acetoacetate in amounts of $1-10 \mu \mathrm{g}$. is described.

2. The method depends on a reaction between acetoacetate and diazotized $p$-nitroaniline to form $N, N^{\prime}$-bis-( $p$-nitrophenyl)- $C$-acetylformazan. Under the conditions employed the reaction takes place reproducibly and quantitatively.

3. The method has been applied to the study of acetoacetate formation by suspensions of rat liver and to the measurement of acetoacetate levels in blood.

The author wishes to thank Professor H. A. Krebs, F.R.S., for help and advice during the progress of this work.

\section{REFERENCES}

Bamberger, E. (1892). Ber. dtsch. chem. Ges. 25, 3547.

Bamberger, E. \& Lorenzen, J. (1892). Ber. dtsch. chem. Ges. 25, 3539.

Chattaway, F. D. \& Ashworth, D. R. (1933). J. chem. Soc. p. 475.

Edson, N. L. (1935). Biochem. J. 29, 2082.

El Hawary, M. F. S. \& Thompson, R. H. S. (1953). Biochem. J. 53, 340.

Greenberg, L. A. \& Lester, D. (1944). J. biol. Chem. 154, 177.

Japp, F. R. \& Klingemann, F. (1888). J. chem. Soc. 53, 519.

Krebs, H. A. (1942). Biochem. J. 36, 303.

Krebs, H. A. \& Eggleston, L. V. (1945). Biochem. J. 39, 408.

Lehninger, A. L. (1949). J. biol. Chem. 178, 625.

Lehninger, A. L. \& Smith, S. W. (1949). J. biol. Chem. 181, 415.

Ljunggren, G. (1924). Biochem. Z. 145, 422.

MacKay, E. M., Carne, H. O., Wick, A. N. \& Visscher, F. E. (1941). J. biol. Chem. 141, 889.

Meyer, V. (1877). Ber. dtsch. chem. Ges. 10, 2075.

Rosenthal, S. M. (1949). J. biol. Chem. 179, 1235.

Stadtman, E. R., Doudoroff, M. \& Lipmann, F. (1951). J. biol. Chem. 191, 377.

Stark, I. E. \& Somogyi, M. (1943). J. biol. Chem. 147, 319.

Wohl, A. \& Claussner, P. (1907). Ber. dtsch. chem. Ges. 40, 2308.

Wohl, A. \& Oesterlin, C. (1901). Ber. dtsch. chem. Ges. 34, 1139. 